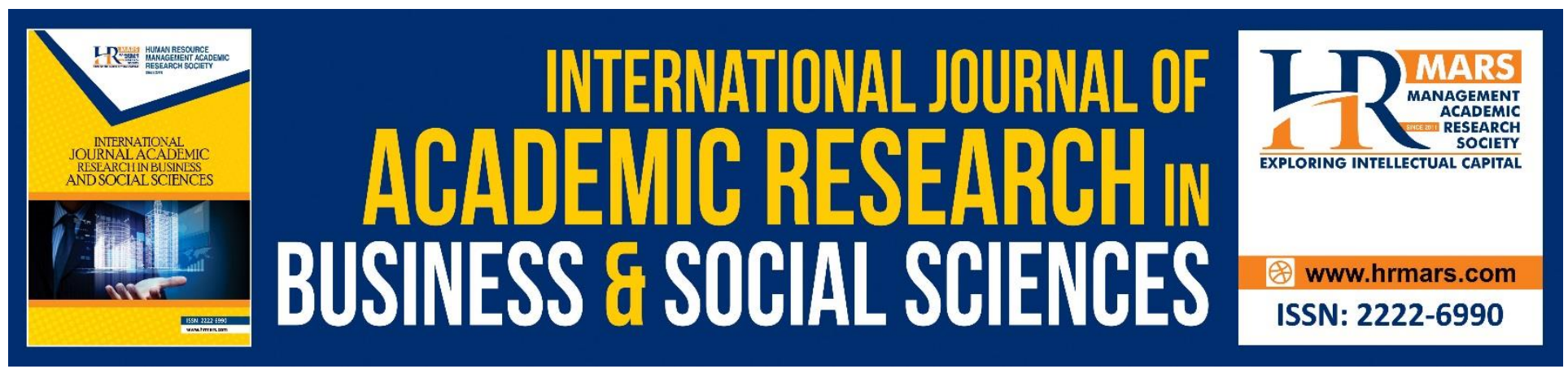

\title{
The Feasibility Study in Digitization of Records and Archives
}

Eiressziennie Zakaria, Saiful Farik Mat Yatin, Elia Elizaberth Rujilis, Nadiah Abdul Hamid

To Link this Article: http://dx.doi.org/10.6007/IJARBSS/v8-i9/4653

DOI: $\quad 10.6007 /$ IJARBSS/v8-i9/4653

Received: 01 August 2018, Revised: 27 August 2018, Accepted: 29 Sept 2018

Published Online: 15 October 2018

In-Text Citation: (Zakaria, Yatin, Rujilis, \& Hamid, 2018)

To Cite this Article: Zakaria, E., Yatin, S. F. M., Rujilis, E. E., \& Hamid, N. A. (2018). The Feasibility Study in Digitization of Records and Archives. International Journal of Academic Research in Business and Social Sciences, 8(9), 758-769.

Copyright: (C) 2018 The Author(s)

Published by Human Resource Management Academic Research Society (www.hrmars.com)

This article is published under the Creative Commons Attribution (CC BY 4.0) license. Anyone may reproduce, distribute, translate and create derivative works of this article (for both commercial and non-commercial purposes), subject to full attribution to the original publication and authors. The full terms of this license may be seen

at: http://creativecommons.org/licences/by/4.0/legalcode

Vol. 8, No. 9, September 2018, Pg. 758 - 769

http://hrmars.com/index.php/pages/detail/IJARBSS

JOURNAL HOMEPAGE

Full Terms \& Conditions of access and use can be found at http://hrmars.com/index.php/pages/detail/publication-ethics 


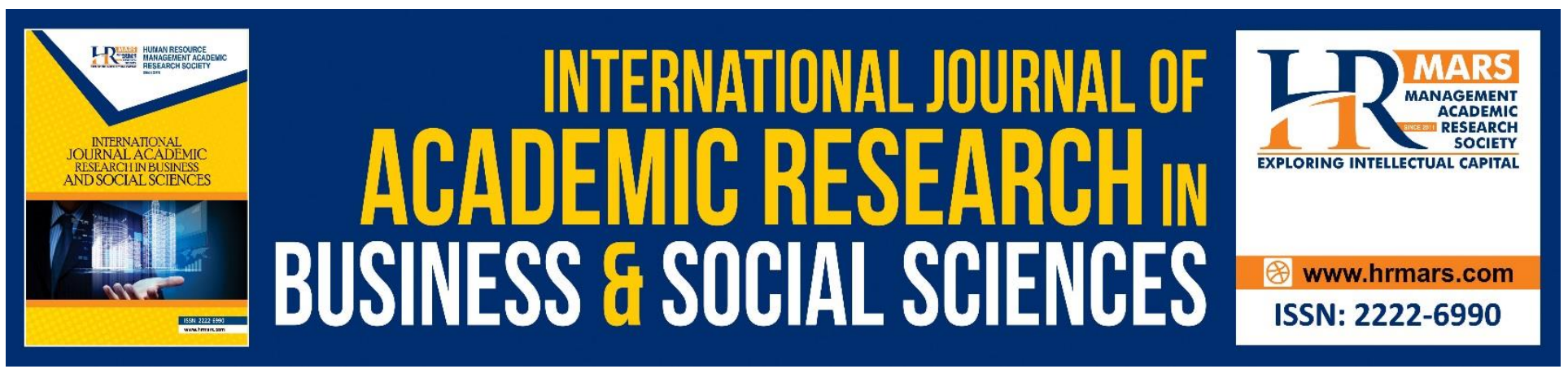

\title{
The Feasibility Study in Digitization of Records and Archives
}

\author{
Eiressziennie Zakaria, Saiful Farik Mat Yatin, Elia Elizaberth Rujilis, \\ Nadiah Abdul Hamid \\ Faculty of Information Management, Puncak Perdana Campus, Universiti Teknologi MARA (UiTM), \\ UiTM Selangor, Malaysia
}

\begin{abstract}
The definition of feasibility study is the analysis of a problem to determine if it can be solved effectively. Digitization content may include text, sound, image and voice are stored as electronic files and viewed and edited on a computer. The term is often used for the scanning of analogue sources, such as printed photos or taped videos into computers for editing, but it also can refer to audio and textures map transformation. There are several problems that being faced by the organization that make a digitization of their collection related to limited access of their collection. The more technology advances, the more converged the system of digitization that can increase the cost of maintenance to make sure that the digitization system functions well. Due to the fact that digitization will incur a huge cost, feasibility study is needed to assess the strength, weaknesses, opportunity and threats (SWOT) of a proposed project and present direction and interventions of activities which will improve a project and achieve the desired results. This paper discusses about various issues in feasibility study in digitization of records and archives such as legal, political, economic, social, cultural, technical, safety, environmental, managerial, financial, market and organizationally feasibility.
\end{abstract}

Keywords: Feasibility Study, Digitization, Electronic Document Management, Records, Archive

\section{INTRODUCTION}

Mahesh and Mittal (2009) stated that feasibility study has been prescribed and described as an important step in information system development. One of the key issues pertaining to the feasibility study is its time of preparation and presentation during the system development life cycle. Systems analysis and design suggest that different timings for its preparation and presentation; feasibility studies are not being performed on a formal basis and that the timings used by them are different from the ones recommended by texts, and there is a divergence of views among analysts and users regarding the appropriate feasibility study timings. 
Digitization content may include text, sound, image and voice are stored as electronic files and viewed and edited on a computer. The term is often used for the scanning of analogue sources, such as printed photos or taped videos into computers for editing, but it also can refer to audio and textures map transformation. Due to the fact that digitization will incur a huge cost, feasibility study is needed to assess the strength, weaknesses, opportunity and threats (SWOT) of a proposed project and present direction and interventions of activities which will improve a project and achieve the desired results. Among the cost for a digitization project such as preparing documentation, equipment and space (scanning equipment, hardware and software), human resources, insurance costs (if related to transportation or fragile materials), storage and ongoing maintenance.

\section{DEFINITION FEASIBILITY STUDY}

Feasibility study is the analysis of problems to determine if it can be solved effectively. It carried out in order to assess the viability of a new project. Cambridge Advanced Learner's Dictionary and Thesaurus (2017) define it as an examination of a situation to decide if a suggested method, plan, or piece of work is possible or reasonable. A feasibility study is used to determine the viability of an idea, such as ensuring a project is legally, technically, economically, socially and organizationally justifiable. It tells us whether a project is worth the investment-in some cases; a project may not be doable. Zkjadoon (2016) on the other hand define feasibility study is an analytical program through project manager determines the project success ratio and through feasibility study project manager able to see either project will useful or not and how much time, it will take to get completed. Also, feasibility study allows project manager to determine all positive and negative points of the project.

\section{ISSUES TO CONSIDER}

\section{Limited Access}

There are several problems that being faced by the organization that make a digitization of their collection related to limited access of their collection. The more technology advances, the more converged the system of digitization that can increase the cost of maintenance to make sure that the digitization system functions well. For example, the Internet has transformed many communication norms, creating more efficiency for not only individuals but also businesses to the organization itself.

\section{Inefficiency}

Inefficiency in business processes are surpassing beyond level of tolerance, because almost all records and archives material are under restricted or no access status due to their physical condition, poorly organized, indexed and usually difficult to locate, fragile cultural heritage are under threat due to deterioration losing vital contextual information, restricted scholarly interest, absence of disaster management plans, absence of sharing of information between institutions; restricted educational, economic, political, social and cultural development and overwhelming current records which prevents giving attention to retrospective materials. 


\section{Preservation}

The next problem in digitization is related to preservation that aiming at conserving and preserving old, fragile and deteriorating documents of high scholarly value that become possible once the documents are available in computer-processible form.

\section{FEASIBILITY STUDY}

Any digitization project need to consider every aspect of feasibility study which involves determining whether it is Legal, Political, Economic, Social, Cultural, Technical, Safety, Environmental, Managerial, Financial, Market and Organizationally is achievable (Zkjadoon, 2016). Due to the fact that digitization project involved various kinds of extended needs as compared to the implementation of a normal information system. The need of special hardware (scanner, jukebox), software (Optical Character Recognition, Intelligent Character Recognition), skill staff (conservator, archivist, image expert), types of materials (archives, documents, books, manuscript) etc. It is recommended that every digitization project should consider every angle of feasibility study to reduce the risk of making incorrect decisions. Some of the feasibility study that need to be considered are:

\section{LEGAL FEASIBILITY}

It determines whether the proposed system conflicts with legal requirements such as data processing system must comply with the local data protection regulations. If there is a proposed joint venture, collaborations, digital consortium, consultancy, outsourcing is acceptable in accordance to the laws in the country. Copyright issues (Hudson and Kenyon, 2007), liability for infringement, licensing options, fair use are among the issues concern (United State Copyright Office, 2011). In Malaysia, there are scholarly works on copyright law which examine the exclusive rights of copyright owners under the Copyright Act 1987 ('CA 1987'), which is the statute governing copyright in Malaysia (Khaw 2008; Ida Madieha 2012; Tay 2013; Tay, et al. 2017).

Rieger (2010) suggest that in massive digitization collaboration with commercial or non-profit organizations such as Google or the Internet Archives are essentials. Digitization project is a very expensive process. Therefore, institution should consider to collaborating with others. This collaboration will help the institution to manage the costs. However, there are many issues that should to be managed before institution considers collaboration with others organization in a digitization project. For instance, under what terms will end user have access to contents? These issues need to be address to maximise opportunity of the organization to collaborate with non-profit organization.

\section{Identify legal and copyright}

Riley-Reid, (2015) mentioned that there is identify legal and copyright issues in digitization project. It has become the biggest issues in digitization regarding copyright of materials. There is a copyright laws and ownership that have been implemented accordance with the digital revolution. However, this rules and laws do not match with the demands and needs of users of digital materials. Despite the recent update and amendments to the laws, it is still not suitable to be apply to digital materials. The copyright law that were being established, when books are simply paper editions, are not 
accordance with digitization materials. Ironically, even the updates of the laws that had being establish, had bring out more problems to the institutions. The deficiency of laws had brought bad image to the archive and other institutions because they are deemed as scoff laws. The relationship between archive and copyrights holder also had turn so badly such as how to transfer copyright ownership, half or full copyright transfer. Canadian Heritage Information Network (2000) suggestions on appropriate copyright clearances:

- When the underlying materials are still protected by copyright:

Should ensure that the material being digitized has been licensed for reproduction. Authorizations should be obtained from the owner/creator of the materials. If the materials are in the public domain, such authorization is no longer needed.

- When the materials are still protected by copyright:

Since the digitization of existing materials is also a reproduction, should ensure that they hold the rights to digitize the materials. Such rights can be obtained by ensuring the holds of the copyright through an agreement by negotiating these rights when the materials have been digitized. If the materials being digitized fall into the public domain, then these authorizations are, of course, no longer needed.

- When the digitized image will be modified:

If, in the course of digitization, the image is somehow modified or cropped or discoloured; rights associated with copyright, such as moral rights, may become an issue. Moral rights are held by the owner/creator of the original materials that is the subject matter of the image. Photographers also hold moral rights in their photographs even when copyright has been assigned to another party. Moral rights run for the length of copyright and cannot be transferred; they can, however, be waived.

\section{POLITICAL FEASIBILITY}

Some of the directions for the proposed project are mostly dictated by the political considerations. This is certainly correct for large projects with potential visibility that may have important political implications and government inputs. For example, regardless of the merit of project, the political necessity may be a source of assistance for a project. On the other hand, because of political factors, valuable projects may face uncontrollable disagreement. An evaluation of the objectives of project with the current objectives of the political system is required in the political feasibility analysis.

\section{ECONOMIC FEASIBILITY}

Office of Financial Management (2017) define the purpose of an economic feasibility study (EFS) is to demonstrate the net benefit of a proposed digitization project for accepting or disbursing electronic funds/benefits, taking into consideration the benefits and costs to the agency, other state agencies, and the general public as a whole. The EFS is composed of two required forms:

\section{Business Case}

The Business Case provides an analysis of the business environment including, but not limited to, a description of who the expected users are, the nature of the digitization project, how the payment is currently being processed, if applicable, and the current and expected volume and timing of transactions. The Business Case also presents the benefits of the proposed digitization project. The 
INTERNATIONAL JOURNAL OF ACADEMIC RESEARCH IN BUSINESS AND SOCIAL SCIENCES

Vol. 8, No. 9, Sept. 2018, E-ISSN: 2222-6990 (C) 2018 HRMARS

Business Case includes a description of the assumptions made in the economic feasibility analysis and the reasoning behind those assumptions.

\section{Cost Benefit Analysis}

The Cost Benefit Analysis summarizes the revenues and costs involved with the proposed digitization project. The amounts in the Cost Benefit Analysis should reflect the amounts and assumptions in the Business Case. An analysis summarizing the impact to the organization and the stakeholder, as applicable.

\section{SOCIAL FEASIBILITY}

The affect that a proposed digitization project may have on the social system in the project environment is addressed in the social feasibility. The influence on the social status of the participants by the project should be evaluated in order to guarantee compatibility. It must be identified that employees in the particular industries may have specific status symbols within the society. Şentürk (2014) suggest that, a digitization project need to address the issues on the user. Digitization project should be able to serve the various need of various type of user of the digital archive. For instance, they are various situations where the need of users is different based on the evaluation of assessment of the project's impact on the lives of people that live and work in the project's area of influence since many infrastructure initiatives cause severe adverse impacts on communities surrounding the site on which they are implemented. It is an exercise aimed at identifying and analysing such impacts in order to understand the scale and reach of the digitization project's which ensures that these impacts are mitigated, to the extent possible, and fully considered in the green light decision. It helps to reduce resistance, strengthens general support, and allows for a more comprehensive understanding of the costs and benefits of the project.

\section{CULTURAL FEASIBILITY}

The compatibility of the digitization proposed project with the cultural environment of the project is included in the cultural feasibility. Planned operations should be integrated with the local cultural beliefs and practices in labour intensive projects. For example, what a person is willing to perform or not perform is influenced by his religious beliefs.

\section{Special Collection}

Erway (2011) a special collection is a group of items such as rare books or documents that are either irreplaceable or unusually rare and valuable. Certain of archives are using large scale of digitization in order to digitize their manuscript collection. For examples the Archives of American Art collection contains of manuscripts, photographs, slides, sketchbooks, scrapbooks, diaries, postcards, posters, and rare published materials.

\section{TECHNICAL FEASIBILITY}

Technical capability of the projected technologies and the capabilities of the personnel to be employed in the digitization project. In certain examples especially when projects are in third world countries, technology transfer between cultures and geographical areas should be analysed. By doing 
so, implications are understood due to the differences in technical skills, infrastructure support and other problems.

\section{Create/Maintain Metadata}

A digital asset availability is depending on metadata. In order to stay away from possible losses, it is necessary for the institution to have a clear metadata policy. The policy need to be established to describe on how to manage digital assets. There are four categories of metadata which is administrative, technical, descriptive and structural. All of these elements need to be included for long-term preservation because each of them is important to construct a complete metadata infrastructure. Furthermore, by having this metadata the process of migration to update software formats will be easier and the change of data losses could be avoided. Effective metadata plan will keep the data intact and each update could be done smoothly.

\section{Selection Issues}

Brown (2008) in his report stated that the selection of file formats for creating electronic records should be determined not only by the immediate and obvious requirements of the situation, but also with long-term sustainability in mind. An electronic record is not fully fit-for-purpose unless it is sustainable throughout its required life cycle. Minimising the number of separate file formats involved is a great practice in managing large collection of electronic record. It is useful to identify a minimal set of formats which meet both the active business needs and the sustainability criteria, and restrict data creation to these formats. For instance, selecting file formats for migration issues, where formats for migration must meet the requirements for both preservation of authenticity and ease of access.

\section{Preservation and Re-Use Perspective}

There is an issue of conflict between the need for data formats that can be accessed and those that can be re-used. From a preservation and re-use perspective, data must be maintained in a form that can be processed, but for the purposes of access, however, control of the formatting may well be the most important criteria. So, it may be desirable for the data not to be able to be processed by end users. To address these issues when selecting file formats data creators should considered the following criteria stated by The National Archive of Digital Preservation Guidance Note 1: Selecting file formats for long-term preservation that are ubiquity, support, disclosure documentation quality, stability, ease of identification and validation, intellectual property rights, metadata support, complexity, interoperability, viability, and re-usability. Selection decision will greatly enhance the sustainability of the records created.

There are many issues to be considered when selecting file formats as it is not possible to select formats that meet all criteria in every case. But, new formats and revisions of existing formats are constantly being developed. The guidance should be able to help and assist data creators to make informed decisions about file format selection from the ever-changing choices available. 


\section{Technical Issues}

The technical issues that always happen in digitizing a documents archival material which is the types of scanner the archives use. Research by Ezeani (2009) stated that some archives in other countries such as Nigeria, their environmental condition is quite challenging, rural and urban area and their collection also many then the archives should determine what types of scanner that suitable with their physical environment condition. The archives should determine the cost of the scanner, the ability of the scanner to work in those kinds of environment therefore the criteria that should be considered when purchased scanner such as image quality, resolution, bit depth, image enhancement processes, the equipment and its performance and many more, this technical requirement must be determine whether the technical requirement meet capacity. Therefore, the team of archives must acquire advance scanner so that the technical team capable of converting the ideas into working system.

\section{SAFETY FEASIBILITY}

Another important aspect that must be considered in the digitization project planning is the safety feasibility. Safety feasibility involves the analysis of the project in order to ascertain its capacity to implement and operate safely with least unfavourable effects on the safety for the staff (preparing the materials) and the materials being digitize such as not necessary to keep exposing objects to handling and light).

\section{ENVIRONMENTAL FEASIBILITY}

Environmental aspect is very crucial in making any potential project successful or failed. In the very early stages of the project, this aspect should be considered. All the environmental concerns raised or forecasted should be addressed in environmental feasibility so that proper actions can be taken to cover relevant issues of the environment. The ability of the project to timely acquire the required permits, licenses and approvals at a reasonable cost should also be included in this area.

\section{Biological Agents Mould, Insect and Rodents}

International Records Management Trust (1999) points out that the problem of the deterioration of books and archival material caused by biological agents assumes serious proportions in many countries. Frequently precious collection of books and documents suffer damage which cannot be repaired even with the help of restoration techniques. Before the digitization project done, the collection of book in archives that need to be digitized should be identifying in terms of the condition of the books. This is important so that the digitization processes work effectively. There is certain issue when the archivists digitizing some of their collection in archive which is they face some biological agents such as mould, insect and rodents.

\section{MANAGERIAL FEASIBILITY}

Managerial feasibility is ascertained by certain key elements like employee involvement, demonstrated management availability and capability and commitment. The managerial and organizational structure of the digitization project is addressed by this feasibility which ensures that the proponent's structure mentioned in the submittal is feasible to the kind of operation undertaken. 


\section{FINANCIAL FEASIBILITY}

Financial feasibility must be differentiated from economic feasibility. The ability of the project management to raise sufficient funds required to implement the proposed project is included in the financial feasibility. Additional investors and other sources of funds are considered by the project proponents for their projects in many cases. In such situations feasibility, sources, soundness and applications of these project funds may be a hindrance. Riley-Reid, (2015) stress that any digitization project needed to thinks, where will the money for the digitization come from? A lot of money needed to be invest in digitization project, a budget gets eliminated together, the organization will have a hard time taking on the added responsibility of digitization project.

\section{Cost Digitization Project}

The issue regarding on cost digitization project which is the cost of digital archive system and functionality for the long-term preservation of digital records, personnel costs which involved in the operation of digital archives system. Research by Jacqueline Slats and Remco Verdegem (2005) illustrated the cost of digital archive system and functionality for the long-term preservation of digital archives includes the physical space, hardware and software for the digital archive system. In order to store records in digital form the archives must require a system for storage and long-term preservation. Therefore, it recommends that the archives should set up separate development, test and production facilities for long term preservation.

Hardware is the most important item to store the records; the hardware could be the servers, storage media and backup equipment. This cover issue such as what types of hardware that need to purchase, is it the hardware suitable to be apply with the various collection of archives and where to buy the cheaper of hardware which suit the budget of the archives. Next is the software for digital archives system, the software which includes such as operation system (OS), application, security and communication software. The issue regarding on the software which is what types of operating system and standard software for the database. The archive also should need a protection software to against the viruses and unauthorized access. Research by Jacqueline Slats and Remco Verdegem (2005) also gives an opinion about the personnel cost of staff that involved in the operation of a digital archive and preservation system. Is it the staff should be recruit in the archives, the staff could be recruit or selected in archives based on their knowledge and skills? Through this personnel cost they have been divided into three section of personnel which is digital archive system personnel whereby the staff need to design and construct the digital archives, preservation system personnel which is the staff responsible for the preservation system which establish the quality control system, the SOP and the procedures.

\section{MARKET FEASIBILITY}

Market feasibility must not be mixed up with the economic feasibility. The potential influence of market and user demand, competitive activities and available market share should be considered in the market feasibility analysis. During the start-up, ramp up and commercial start up phases of the digitization project, possible competitive activities (local, regional, national and international) should be analysed for early contingency funding and impacts on the operating costs. 


\section{ORGANIZATIONAL FEASIBILITY}

Organizational feasibility analysis is conducted to determine whether a proposed business has sufficient management expertise, organizational competence, and resources to successfully launch its digitization project. There are two primary issues to consider in this area:

Management prowess - that determine the prowess, or ability, of its initial management team.

Resource sufficiency - that determine whether the proposed venture has or is capable of obtaining sufficient resources to move forward.

\section{Planning a Digitization}

In planning a digitization projects, there are variety of aspects need to be considered. Firstly, issues that involve in the planning is determining goal (Riley-Reid, 2015). A clear goal for digitization need to be established by all of those involved. From the very beginning of this digitization project, it is essentials to have a clear agreement between the entire departments that involved in the digitization and stakeholder on what the project need and cost to them. Clear projects ideas need to be establish. Apart from that, the institution must also examine the all of the aspects of the project. For example, do the materials that are digitized will be made available for all users to access on the Internet or did it could only made available through the institution's Intranet? Also, some key goals of a preservation policy should be to: maintain physical control of the repository; care for the physical media; identify and retrieve the data into the future; and to keep the digital objects "whole and unimpaired [...] [so that] all the parts relate to each other," (Dappert and Enders, 2010).

\section{Assess the Collection}

The user should be carefully examined. Research need to be done in the organization to identify any materials that might benefits from being digitized. Archives hold a lot of material over the years, new materials keep coming in so it can be easy to lose track of certain things. Usually, materials which are not part of the regular collection or not catalogued are items that the archivist have fail to assess.

\section{Analyse Work Flow}

The analyse work flow issues also should be examine in digitization project. It is important for the institution to find out on how project of digitization project will work together. They also need to discuss on how the work flows in the project will operate between these entities. Organization need to assign a clear responsibility of department that involved in the digitization project. For instance, assign clearly which department should be responsible for handling the digitizing project? Also, they need to be informed if there is a need to form or developed of a new unit of department to handle the digitization project.

\section{Good Quality Image}

Riley-Reid, (2015) opines that in digitization project it is essential to ensure the good quality materials are produced. Institution need to make sure whatever materials that have been digitized is in good 
INTERNATIONAL JOURNAL OF ACADEMIC RESEARCH IN BUSINESS AND SOCIAL SCIENCES Vol. 8, No. 9, Sept. 2018, E-ISSN: 2222-6990 @ 2018 HRMARS

quality. For example, if the item is a picture, are the images still clear and focused. Materials that are digitized need to be clean and clear. There are also issues regarding the usability and viability of the digital content. Digitized materials should be authentic. Therefore, to proven this, the institution need to able to explain further and analyses the digitized materials.

\section{Educate/Train (Users and Staff)}

Riley-Reid (2015) consider who will be assign to be in charge of for preserving and transmitting new content to the digital repository? The staffs responsible are from which department. Do all the employees need training or it involves only the new employees. A staff could not manage without proper training. Staff need to be send for training as they must have an understanding of the underlying some concepts of information technology and computing.

\section{CONCLUSION}

The purpose of this feasibility study was to determine various alternatives in planning the digitization project. Not all types of feasibility are related or suitable to certain project, but some of it should be consider due to high cost in implementing this digitization system.

\section{REFERENCES}

Bayissa, G, Ketema, G. \& Birhanu, Y. (2010). Status of Digitization Process in Selected Institutions of Ethiopia: A Baseline Stakeholders' Analysis Survey Report, Vol. 5 (2)

Brown, A., (2008) Selecting File Formats for Long-Term Preservation. The National Archives, from: http://www.nationalarchives.gov.uk/documents/selecting-file-formats.pdf

Cambridge Advanced Learner's Dictionary and Thesaurus (2017). Date retrieved Dec, 22 from https://dictionary.cambridge.org/dictionary/english/feasibility-study

Canadian Heritage Information Network (2000). Capture your Collections: A Guide for Managers Planning and Implementing Digitization Projects

Minister of Public Works and Government Services Canada. Date retrieved 27 Jan 2018 from: https://www.canada.ca/en/heritage-information-network/services/digitization/capturecollections-guide-managers/planning-implementing-projects-guide-managers.html

Copyright Act 1987 (Act 332).

Copyright (Amendment) Bill 2010.

Dappert, A. and Enders, M. (2010), "Digital preservation metadata standards", Information Standards Quarterly, Vol. 22 (2), pp. 156-166.

Ezeani, C. N. (2009). Digitizing projects in developing countries: the case of the University of Nigeria. Library Hi Tech News, Vol. 26 (5/6), pp. 14-15. doi:10.1108/07419050910985273

Erway, R. (2011). Rapid Capture: Faster Throughput in Digitization of Special Collections. Dublin, Ohio: OCLC Research. Retrieved from http://www.oclc.org/research/publications/library/2011/2011-04.pdf.

Hudson, E. and Kenyon, A.T. (2007). Digital access: The impact of copyright on digitization practices in australian museums, galleries, libraries and archives. UNSW Law Journal, Vol. 30 (1), pp. 12-52. 
INTERNATIONAL JOURNAL OF ACADEMIC RESEARCH IN BUSINESS AND SOCIAL SCIENCES Vol. 8, No. 9, Sept. 2018, E-ISSN: 2222-6990 (C) 2018 HRMARS

Ida Madieha, A.G.A. (2012). Copyright law in Malaysia: Cases and commentary. $2^{\text {nd }}$. ed., Petaling Jaya, Malaysia: Sweet \& Maxwell.

International Records Management Trust (1999). Retrieved from www.irmt.org/documents/educ_training/public_sector.../IRMT_preserve_recs.doc

Khaw, L.T. (2008). Copyright Law in Malaysia. 3rd. ed., Petaling Jaya: LexisNexis.

Lampert, C.K. and Vaughan, J. (2009), "Success factors and strategic planning: rebuilding an academic library digitization program", Information Technology and Libraries, Vol. 28 No. 3, p. 166.

Mahesh, G. \& Mittal, Rekha, (2009),"Digital content creation and copyright issues", The Electronic Library, Vol.27 Iss 4 pp. 676 - 683 Permanent links to this document:

http://dx.doi.org/10.1108/02640470910979615

Office of Financial Management (2017) Economic Feasibility Study. Date retrieved Dec, 22 from https://www.ofm.wa.gov/sites/default/files/public/legacy/policy/40.40.htm

Rieger, O. Y. (2010). Enduring Access to Special Collections: Challenges and Opportunities for LargeScale Digitization Initiatives. RBM: A Journal of Rare Books, Manuscripts, and Cultural Heritage, 11(1), pp. 11-22

Şentürk, B. (2014). Effective Digitization in Archives. Journal of Balkan Libraries Union, Vol. 2 (1), pp. 11-15.

Tay, P. S. (2013). Intellectual Property Law in Malaysia. Petaling Jaya: Sweet \& Maxwell.

Slats, J \& Verdegem, R. (2005). Cost Model for Digital Preservation. Retrieved from https://pdfs.semanticscholar.org/1b4f/ab8416d0b2a4e2 2b2d7ab00b2715397e91d9.pdf

Riley-Reid, T. D. (2015) The hidden cost of digitization - things to consider, Collection Building, Vol. 34 (3) pp. 89 - 93. doi: http://dx.doi.org/10.1108/CB-01-2015-0001

United State Copyright Office (2011). Legal Issues in mass digitization: a preliminary analysis and discussion document, Register of Copyrights. Retrieved on Dec, 22 from https://www.copyright.gov/docs/massdigitization/USCOMassDigitization_October2011.pdf

Webb, C., Pearson, D. and Koerbin, P. (2013), "'Oh, you wanted us to preserve that!' Statements of preservation intent for the National Library of Australia's digital collections", D-Lib Magazine, Vol. 19 Nos 1/2, p. 2.

Zkjadoon (2016) What is Feasibility Study: types of feasibility studies. Business Study Notes. Date retrieved Dec, 23 from http://www.businessstudynotes.com/finance/projectmanagement/types-feasibility-study/ 